vol. 31 - n² | 2015

Majorité et minorités : un rapport à repenser

\title{
Cosmonational Integration of Diaspora Enclaves
}

L'integration cosmonationale des enclaves diasporaines

Integración cosmo-nacional de los enclaves de la diáspora

Michel S. Laguerre

\section{(2) OpenEdition}

Journals

Electronic version

URL: https://journals.openedition.org/remi/7265

DOI: $10.4000 /$ remi.7265

ISSN: $1777-5418$

\section{Publisher}

Université de Poitiers

\section{Printed version}

Date of publication: 1 June 2015

Number of pages: $55-78$

ISBN: 979-10-90426-25-2

ISSN: 0765-0752

\section{Electronic reference}

Michel S. Laguerre, "Cosmonational Integration of Diaspora Enclaves", Revue européenne des 


\section{Cosmonational Integration of Diaspora Enclaves}

\section{Michel S. Laguerre ${ }^{1}$}

The study of immigrant communities has for many years been carried out in terms of majority-minority relations-that is, confined to interactions between the mainstream and the most prominent ethnic group in the country. In the United States, this was translated to mean the Anglo community and the African American component of the population because of their demographic size and geographical spread throughout the country and also because of the asymmetry of power they project and represent. The assumption behind this choice is that findings obtained in this context can be transported to shed light on the relations of other immigrant groups with the dominant sector of society. This is how the black and white relations model has become prototypical, providing the methodological and theoretical lens through which other immigrant groups can be studied. Such an approach has also become the target of critics which refer to it as a "failure of a perspective" not only because of its lack of attention to the diversity and peculiarity of other diasporic groups such as Latinos and Asian Americans in their relations with the Anglo mainstream, but also because it was couched within the context of the nation-state seen as a container for these interactions (McKee 1993; Laguerre 1999). In shifting the frame of analysis from the nation-state to the unbound nation, the majority-minority relations framework has slowly lost its explanatory power and prominence in the sociological literature at the expense of other approaches that emphasize issues of mobility, crossborder interactions, human rights, multiculturalism, transnationalism, and globalization, as explained below.

Once we accept the premise that diasporans do not abruptly cut off their ties to the homeland and compatriots wherever they may live, it becomes obvious that studying urban integration uniquely as a local phenomenon constrains our capacity to adequately understand the incorporation problem of immigrant communities and severely narrows our public policy options (Basch et al., 1994; Laguerre, 1998). Diaspora integration implies a process with three differential aims : to bridge the immigrant neighborhood with the hostland, bind the diaspora enclave with the homeland, and bond the ethnopolis to linked diaspora sites of the group inside and outside the country of residence (Kanas et al., 2011).

1 Professor and Director, Berkeley Center for Globalization and Information Technology at the Institute of Governmental Studies, 101 Moses Hall, University of California at Berkeley, Berkeley, California 94720; mlaguerr@berkeley.edu 
A diasporic enclave is a cultural collectivity in a hostland comprising first and subsequent immigrant generations that can be geographically concentrated, territorially dispersed, or exist in virtuality as in "digital diaspora." Multipolar interactions with the homeland and other sites inhabited by the diaspora, which form the multisite nation or cosmonation, constitute a key element of its everyday operation. One speaks then of integration into the hostland as well as into the global circuit of sites that comprise the cosmonation-the transborder social formation that results and emerges from the crisscrossing networks of ties, relations, and interactions between the homeland and the multiple enclaves of its dispersed diaspora, and also among the diverse communities of the diaspora (Sheffer, 2003; Laguerre, 2006; Ben-Rafael and Sternberg, 2009). These three processes of integration feed, are in dialectical tension with, and complement one another. What seems like straightforward assimilation is in fact a networked process of negotiation to achieve cultural harmony, promote equality, sustain social justice, consolidate ethnic solidarity, and engender cosmonational identity.

The process of diaspora integration in a hostland must be envisioned in the larger context of integration in the transnational circuit of the cosmonation because of the interdependence of sites vis-à-vis one another (Laguerre, 2008). There then becomes a need to accurately frame the object of study within the larger parameters and the specific global context in which it is embedded (Sassen, 2001). The concept of the cosmonation was developed to correct what appears to be the greatest deficit in assimilation and transnationalism theories: their inability to conceive of neighborhood integration beyond the hostland or diaspora-homeland binary relations (Laguerre, 2010). The very concept of cosmonational integration indicates that the process is deployed in an expanded space, both geographical and virtual. While a hostland is targeted in most analyses as the primary theater of interaction in any immigrant neighborhood integration model, it is in fact not the sole interlocutor, nor is it always the most important actor in the performance of the process. For these reasons and others, the study of diaspora integration needs reframing in order to articulate more creatively and concretely what is at play and what is at stake.

Here then we seek to reconceptualize diasporic integration as an object of study in order to unveil the true nature and parameters of the problem. In contrast to previous studies of immigrant communities, which use the assimilation or transnationalism approach in the deconstruction of ethnic formations, this new model of integration relocates the ethnic enclave inside a global circuit of interactions, views it as enmeshed in the logic of an ensemble of interlinked sites, and consequently posits integration into a hostland as a cosmonational process.

A review of pertinent literature will contrast the cosmonational model with the assimilation, transnational, and multicultural models of diaspora integration; and a look at how these previous explanations developed will demonstrate how assimilation can also be reinterpreted within the context of the cosmonational model to provide a different vision of the diasporic process. The manner in which the enclave interfaces with the hostland as a node of the cosmonation instead of simply as a local entity will be pinpointed, followed by analysis of two mechanisms-solidarity and competition-by which cosmonational ties of the enclave 
are maintained. A discussion of the porousness of enclave borders and the need to develop municipal public policy for integration, sensitive to both the neighborhood entanglement and engagement with the cosmonation, closes this essay.

\section{Theoretical Background}

In the sociological literature, integration or incorporation is viewed as a local process confined to a limited geographical area that results from the interface of the ethnic community with the hostland (Abrahamson, 1996; Godfrey, 1988). This conceptualization is based on the premise that the ethnic neighborhood is fundamentally a local entity. Framing the problem in this fashion is precisely the argument that is contested here because it fails to adequately recognize the multiple trappings of the enclave's extraterritorial connections and embeddedness with other sites. In order to more accurately depict the parameters of the object of study, this analysis relocates the ethnic enclave into the larger network of cosmonational sites in which it serves as a node. The rationale of its actions can be explained within the context and contours of this transversal ensemble that fuels and shapes the logic of the cosmonation.

Theories of diaspora neighborhood integration have five variations, each with its own package of assumptions and differentiated positioning of variables. One speaks thus of "local" (Brown, 2007), "multicultural" (Fong and Shibuya, 2005), "transnational" (Lainer-Vos, 2010), "global" (Laguerre, 2000, 2003 and 2008; Logan and Zhang, 2010), or “cosmonational" (Laguerre, 2010) approaches to ethnic or diasporic integration. Depending on how one defines the problem and the type of data collected, different approaches have been used. The aim of this paper, however, is to use cosmonational theory to foreground our interpretation of the integration process of diaspora enclaves. Ethnic or civic integration of immigrant communities has been studied from different angles in the sociological literature on race, ethnicity, and ethnic neighborhoods (Brubaker, 2005). The emphasis on specific issues and problems has magnified some aspects more than others and contributed to swaying the interpretation in one way or another. The contents and characteristics of prevalent approaches to immigrant neighborhood integration are summarized as follows.

The assimilationist model has been the privileged approach used by those who frame the issue of diasporic integration as a local problem and therefore identify locality as the primary site for the study of ethnic neighborhoods (Alba and Nee, 2003). In this model a series of mechanisms is singled out-knowledge of the mainstream language, employment status, civic participation, church attendance, voting behavior, and the restrictive policy of the dominant systemto show their contribution to the integration of the ethnic neighborhood into the city. The principal thrust of the policy of the state is then to facilitate the assimilation of the diaspora communities into mainstream culture, practices, and institutional life. In this perspective, assimilation is viewed as the best public policy to prevent recurring social conflict; enhance full employment; undermine both spatial segregation and ghettoization; and promote cultural harmony, collaboration, and solidarity. This is seen most vividly in housing policies geared toward producing ethnically and socioeconomically integrated neighborhoods by dispersing the targeted population (Ham and Manley, 2009). 
In contrast, the transnational approach highlights a different choreography of the ethnic neighborhood phenomenon (Levitt, 2001). The transnational diaspora that inhabits an enclave is seen as one pole of a continuum in constant interaction with the homeland (Radhakrishnan, 2008; Patterson, 2006). In this model, the diaspora and homeland influence each other. The impenetrable frontier envisioned by the assimilationists is seen now as porous because of the fluidity and mobility of the transnational process. Here, integration means the ability to live in one place and engage in activities-communicative, interactive, participatory, financial, and transactional-with others (Shain, 1999). The homeland and the diaspora are theorized as being linked by a transnational social field that serves as an infrastructural corridor, providing a basis of operation and sustainable permanency to these crossborder practices (Pedraza, 1999). Since less emphasis is placed on the relations of the diaspora enclave with the hostland community, transnational integration is usually framed in terms of ongoing extraterritorial relations, transfrontier practices, and the hybridity of bifocal identities. This approach, however, tends to underscore and privilege relations with the homeland over relations with the hostland in an attempt to explain why transnationalism does not eclipse assimilation, but rather how these two processes coevolve (Karim, 2006; Morawska, 2003). Nevertheless, it brings to our attention that locality is not exclusively "local," but is in itself also transnational (Ellis and Almgren, 2009: 1066). Sister-congregation relations that these enclaves maintain with the homeland, for example, attest to the veracity of this proposition.

The multicultural approach-sometimes misnamed as global, to insinuate international-explains the integration of a plurality of ethnicities living in the same neighborhood (Karim, 2006). Like the assimilation approach, it emphasizes locality, but with multiculture complexity-that is, the ability of different groups of people to live next to each other, the dynamics of local democracy, and the forms of cohesion and conflict that cultural pluralism generates (Logan and Zhang, 2010; Krase and Hum, 2007). The multicultural approach, more than any other, brings forth the visibility of the state in the engineering of the plural context of ethnic integration outcome (Labelle and Roger, 2009). States and municipalities use different public policy strategies to reach this goal by advocating and encouraging either a top-down or bottom-up approach. A top-down policy is when the state intervenes to impose regulations to achieve its goal, while a bottom-up approach is when city residents and free markets become the producer and arbiter of such an outcome. In the latter, local people have more freedom to influence the shape of their conditions. As a result, the "global" in this model recedes to the background, with reference to the places of origin of ethnic residents and their immigration history (Hum and Krase, 2004; Logan and Zhang, 2010).

The global approach expands the sphere of interaction to include not only homeland and diaspora relations-the privileged social field of transnationalismbut also relations among diasporas in various sites as well as those between the homeland and specific diaspora sites (Cheung, 2004; Laguerre, 2008). In this perspective, the global approach augments the parameters of the sphere of interaction among ethnic neighborhoods; pinpoints the heterogeneity of homeland and diasporas as nodes of a transnational network; recognizes that a diasporic site may perturb the relations of the homeland with another site; unveils that the homeland may intervene in the relations between diaspora sites; and explicates 
that there is a global architecture reflecting the priority of the homeland in its relations with diverse diaspora sites as well as relations between sites. In doing so, the global model identifies diaspora leaders of associations, ethnic lobbyists, and politicos as mediators and gatekeepers in the integration of diaspora enclaves in both the hostland and the expanded nation. Compared to the aforementioned models, this approach is a more inclusive model because it identifies the relations of the enclave with the homeland, hostland, and diaspora sites in other countries and locates the neighborhood in this larger universe. Thus it sees these relations as an engine for the sustainability of these enclaves. Additionally, the relations of the neighborhood with City Hall are seen as implicating not only the local residents, but also transnational actors in overseas sites. So the neighborhood must be studied not only as a local place, but also as a transnational or global space.

The cosmonational approach used in this essay brings a new vision to the conceptualization of diaspora integration by positioning the problem differently and focusing on and beyond the transnational relations between sites (Laguerre, 2010). The cosmonational framework combines various aspects of the preceding approaches, expands the scope of analysis, and expresses the idea of the logic of the ensemble that one must unveil: how the units interconnect and tie to each other; infrastructures develop to make these ties operational; institutions perform for the benefit of the homeland and all the diaspora sites; and how these crisscrossing networks of sites form a cosmonation while each enclave maintains its own identity because of geographical location, demographic composition, diaspora or homeland status, and standing in the transnational network of sites. In other words, the cosmonational approach frames and advances the idea that the interconnected sites form an ensemble and seeks to unveil the logic of such a network (Laguerre, 2013). It further explains that whatever occurs within the parameters partakes, reflects, or influences the entire platform.

\section{Reimagining Integration}

Diasporic integration is played out at three levels. It has a policy component (the domain of the state), an agency or motivational aspect (the role of immigrants), and a local and extraterritorial dimension (relations with the surrounding community, the state of origin, and family and compatriots in the homeland and abroad). The policy angle illuminates the role of the receiving state in carving out regulations for the integration of the diaspora. Over the years, states have developed and implemented diaspora policies based on models from assimilation to multiculturalism, contingent on the outcome they want and project to achieve (Kymlicka and Banting, 2010). They have been less open to the idea of transnational and global diaspora policies for reasons of protection of national security and fear of losing control over their national sovereignty (Sassen, 2001). The agency or motivational dimension refers to the extent to which residents of diasporic neighborhoods want full integration. In such a scenario, attachment to one's native culture is viewed by the mainstream as a hindrance to assimilation and the achievement of parity. Finally, the extraterritorial dimension refers to the ability of an enclave to maintain ongoing relations with both the homeland and variegated heterogeneous types of diasporic sites. 
Integration of the ethnic neighborhood into the hostland has been studied from various angles to demonstrate its embeddedness in the local urban environment (Aytar and Rath, 2012; Roseman et al., 1996). Although these local practices may also have a transnational, global, or cosmonational dimension, they were seldom analyzed through these prisms and theoretical lenses. In fact, the focus on local practices tells us only one side of the story, pertaining to interactions with the hostland but at the expense of understanding relationships with the homeland and other diasporic sites. The local practices are nevertheless important to analyze as they can shed light on one pole of the continuum and, through further interpretation, on cosmonational implications. In any case, this narrow perspective alerts us to the bias brought about by an exclusive focus on locality.

Previous studies incorporating the assimilation perspective have pointed out how ethnic concentrations have contributed to our understanding of integration in North American cities (Murdie and Ghosh, 2010; Johnston et al., 2002). For example, analysts have identified a number of ills that hamper smooth integration in society. They point to the enclave as a site that impedes proficiency in the official language, hinders the formal acquisition of the mainstream mode of communication, and decelerates the pace of assimilation into the larger surrounding community and the fabric of the city (Evans, 2005; Vervoort et al., 2012). Using a cosmonational lens, the same observation and data can also be interpreted as a show of resilience and continued attachment to the homeland national culture by upholding the channel of communication that links the members of the dispersed group to each other.

Analysts behind assimilation theory further argue that the ethnic enclave facilitates the rise of the ethnic market economy; fosters the development and reliance on ethnic capital; is conducive to a high rate of self-employment; produces employment for the benefit of coethnics; and, in addition, delivers cheap services to customers in and beyond the enclave (Portes and Jensen, 1989; Liu, 2012; Light and Gold, 2000). From a cosmonational angle, the ethnic enclave can also be seen as an outlet, a dumping ground, or market place for selling goods from the homeland and other diaspora communities, thereby transforming the local place into a global site (Laguerre, 2000).

Ethnic concentration has been studied to understand the integration of residents not only in regards to the place of residence, but also other aspects of social, institutional, and associational life. It has been found that demographic concentration of ethnic residents invites racial harassment because of its spatial visibility and, therefore, increased vulnerability to the hostility of the mainstream (Dustmann et al., 2011); this may lead to covert and overt discrimination such as using addresses or zip codes to refuse employment or force members of the diaspora to pay more for services, such as insurance (Magee et al., 2008; Laguerre, 2000). It is viewed by and large as an obstacle to the integration of ethnic minority communities (Bouma-Doff, 2007). Dense population of diaspora groups is blamed for reducing opportunities and incentives for ethnics to develop strong ties with the majority community (Vervoort, 2012) and is conceived as spreading not only at the neighborhood level, but also at the bloc and place of employment level (Özüekren, 2003). Its negative impact on health care, school composition, the labor market, premature age-specific mortality, 
public housing, and ghettoization are staples or insights of the assimilation approach (Bjornstrom, 2011; Lin, 2011). Here again, the emphasis is placed on locality with little attention paid to the role of globality in the production of these outcomes.

A focus on the spatial concentration of ethnics without paying attention to crossborder interactions is limited in what it can offer precisely because in each enclave, residents maintain contact online and offline with other sites; key institutions that provide services and leadership to the enclave belong to coethnics who live elsewhere in the city, if not beyond; and families are dispersed across multiple sites (Montgomery, 2011). Different approaches to neighborhood integration can shed light on different aspects of the problem. Therefore, I agree with Catney, Finney, and Twigg (2011: 107-114) that any attempt to explain diaspora integration is a "complex issue and is difficult to measure, conceptualize and interpret." The meshing of the local with the global, the mobility sustained by diasporic neighborhoods, and the interconnectedness of sites they uphold provide an entry point for a comprehensive intervention in the study of diasporic neighborhoods.

Previous analyses of neighborhood data have been made to support assimilation claims. As we have shown, they can also be interpreted to exhibit the workings of cosmonational integration. Where one sees demographic concentration as a hindrance to assimilation, it can also be seen as an effort to maintain one's culture, thereby reinforcing the enclave as a pole of the homeland, a sister enclave to other sites in which the diaspora has resettled, or simply as a node of a transnational circuit.

\section{Interface of the Diasporic Enclave with the Homeland}

The literature on transnationalism has made us aware of the vibrant ties that connect the homeland to diaspora enclaves and vice versa (Basch et al., 1994; Levitt and Khagram, 2008; Ben-Rafael and Sternberg, 2009). It sheds light on the constant mobility of people, goods, and information from one site to the other, and interaction between localized sites. In fact, the enclave economy would not be successful without capital borrowed from family members in the homeland and elsewhere to start business operations; merchandise purchased from the homeland; and the incoming immigrants that constitute reliable clientele for these commercial ventures (Light and Gold, 2000).

The connections to the homeland begin with the settlement of immigrants in the enclave. As they leave family behind, they continue to maintain contact with them through communication, remittances, and transactions. Short return visits to reconnect with family and friends or take care of property left behind also sustain extraterritorial linkages of enclaves with the homeland.

The business sector constitutes an area in which activities are sustained by transnational connections with the homeland. This is seen not only in the case of in-demand overseas goods sought by the hostland residential community, but also in the ethnic banking system (so-called money transfer houses) that act as couriers for remitting donations to families in the homeland. These are quotidian 
acts as family members on both sides rely on the delivery of this money to care for their loved ones or tend to their daily businesses.

The ethnic radio, ethnic television, and the Internet are additional mechanisms that feed diaspora integration in both the hostland and the homeland (Karim, 2006). The ethnic radio keeps the population abreast of events in the homeland by reporting news and interviewing homeland officials and pundits; the ethnic television does the same while adding captivating images to stories; and diasporans routinely access homeland newspapers, television, and radio programs via the Internet for their daily news. For those who have not adopted the hostland language, these outlets are their only or main information sources for learning about events in their homeland due to language barriers.

The imbrication of the enclave with the homeland is better seen through the playing out of crossborder politics (Sheffer, 2003; Laguerre, 2006; Shain, 1999). Not only do homeland politicians visit the enclave to raise funds for their electoral campaigns and to seek access to elected hostland officials through the mediation of ethnic activists and lobbyists, but diasporans also financially contribute to legislative and presidential campaigns, write stump speeches, and help with campaign publicity (Laguerre, 2006). These extraterritorial political activities are enmeshed in the neighborhood integration process of diasporans in the hostland.

These few examples show how and why transfrontier linkages serve as an engine in the integration process of the diasporic neighborhood in the hostland. The local does not dissociate itself from the global, rather the global is seen through the prism of one of its tentacles (Laguerre, 2007). Again, an exclusive focus on the local would ignore the contribution of the global in the construction and production of locality. The endurance of the relations between the enclave and the homeland elaborates their embeddedness and the reason integration cannot be understood adequately if extraterritorial relations are not analyzed as an intrinsic factor of the enclave integration process.

Interactions with the homeland reveal that integration in the hostland is organically a local process performed in a transnational, global, and cosmonational context. In other words, diaspora integration is in sync with the homeland and other sites of the cosmonation.

\section{Interface of the Diasporic Enclave with the Hostland}

The interface of the enclave with the rest of the city is not exclusively a local phenomenon confined to two local groups of people, even though it occurs in a local place. The role of the homeland and other sites in the social engineering of the outcome perhaps can be best illustrated through an analysis of the ethnic market economy (Light and Gold, 2000). The ethnic market is a local face of a cosmonational transactional event that makes overseas products available to the local residential clientele and others. In the ethnic market, one sees the prolongation of shops and businesses located in the diaspora reflected in the provenance of homeland products. 
The mainstream client act of buying from the ethnic market place signifies three things: first, that the borders that separate the mainstream and the enclave have been crossed for the purpose of engaging in economic transactions; second that these local commercial activities reinforce the theme park status of the enclave, which produces tax revenues for the coffers of City Hall; and third that the local anchorage of the cosmonation (homeland and diaspora) through one of its tentacles is an indicator of the three levels at which the enclave operates. There are selling relations with the local clientele, purchasing relations with the homeland, and exchange relations with other diaspora sites. These three of them are interlocked in the production and reproduction of the diaspora enclave, and any sustainable diaspora policy should pay attention to these factors.

The interaction with the cosmonation is seen when mainstream clients come to buy in the ethnic marketplace. In this encounter, the local face of the cosmonation is unveiled as the items sold may originate from elsewhere, either in the homeland or another diaspora site, and their use may be more common among diasporans than among the mainstream population that sees these goods as exotic.

The variety of products on display and the variety of points of origin indicate how the ethnic marketplace can be seen as a cosmonational dumping ground. Such a site shows multiple cosmonational ties of the enclave with the rest of the network. For trade items to be made available in the enclave requires much long distance communication to agree on prices, order quantity, and select a mode of payment convenient for both sides. Through these mechanisms, the economic life of the enclave is intertwined with that of other sites of the cosmonation. In this light, the success of the enclave depends on its ability to maintain these crossborder relations that feed and nurture ethnic entrepreneurial pursuits. The cosmonationality of ethnic life becomes more visible when we shift our focus from the enclave to other places of the city where contingents of diasporans are found in integrated neighborhoods. These groups participate in the cosmonationality of diaspora life in the city and beyond through associational membership. We find crossborder immigrant associations with leadership that includes diaspora compatriots residing in other countries as well as homeland residents; fundraising by a network of sites of the cosmonation; and projects for the homeland and diasporic communities in distress. These extraterritorial activities unveil the extent of cosmonational engagements of various enclaves that comprise the multisite nation.

\section{Inter-enclave Solidarity and Competition}

In addition to intraenclave solidarity-whereby immigrants who live in the same neighborhood help each other in time of need because of residential proximity, friendship ties, and communal participation in civic associations-there is also interenclave solidarity that interlocks diaspora sites as nodes of the same transnational network. Through these extraterritorial relations they sustain each other in various ways that contribute to the vibrancy of the cosmonational network. These relations materialize in various ways, including interenclave marriages, settlement of family members in more than one enclave, diaspora entrepreneurship and interdiaspora business arrangements, immigrant associations with members from different enclaves, and interdiaspora lobbying efforts directed toward the homeland. 
Precisely because enclaves are part of a cosmonational network, they also manage to compete with each other to show off their successes, leadership, and accomplishments. In the process, each presents itself as a node for other communities to emulate. Sometimes the leader is the node in which most of the rich diasporans and formal political leaders reside, the business community is the most successful, and the creative class congregates-or it may simply be known as the oldest neighborhood of the network. As examples, the competition between Little Saigon in San Jose and the Little Saigon in Los Angeles comes to mind; Little Tokyo in Los Angeles competing with the centrality of Japantown in San Francisco; or Chinatown in New York in competition with Chinatown in San Francisco. These are in-group competitions, comparing one's enclave with others and exhibiting it as the capitol of the network of diaspora sites in an attempt at imposing a certain hierarchical order on the network.

Interenclave relations must also be seen in terms of transnational cooperation. Like cities, enclaves are involved in enclave-to-enclave relationships. Such a form of diaspora-based sister-city model or sister-enclave model unveils a diaspora-diaspora relationship for mutual sustenance in the network. Enclaves establish these informal ties of sisterhood because of proximity, affinity, business relations, religious cooperation, intervention due to a natural or political crisis, or a request from a third party, such as City Hall or some umbrella organization. In any case, this model of sister-enclave relationships is based on diaspora ties.

In this analysis, one must distinguish the sister enclave model from the diaspora-mediated sister-city model. The latter proceeds from a different logic as it serves as a channel in the formation and sustenance of a sister-city apparatus. Here, City Hall calls on the diaspora to serve as an intermediary in its relations with a city in the diaspora's homeland, or the diaspora may even initiate the process of bringing the two parties together to form a sister-city relationship. In contrast, the nondiaspora-mediated model proposes a strategy whereby two cities become sisters without the intervention of a diaspora group.

It is important to highlight that diaspora enclaves thus generate three types of sister-city or twinning relations. It is equally significant to note that these forms of small-scale sister-city relations are similar, but not identical, to the traditional sister-city model established with overseas partners by mainstream cities (Viltard, 2008). The main difference is that the traditional sister city is a relationship that engages two groups of people, not blood related and not belonging to the same ancestral homeland. In contrast, sister enclaves refer to the same cultural group distributed in the homeland and different diaspora sites.

Three distinct forms of sister-enclave relations can be identified based on the principle of their organization. Sister enclave by descent is a crossborder relationship between two diaspora neighborhoods that are part of the same cultural group. This occurs among first generation immigrants who are now residing in countries apart from their friends, families, and compatriots. The relationships between the enclaves are based on blood and cultural ties and are initiated and controlled by diaspora enclaves. No third party is involved in their formation. It is an informal arrangement in that these enclaves do not elect a mayor to represent them or sign contracts on their behalf, as it is the case with formal sister-city arrangements. 
Sister enclave by affiliation is a different operation, occurring when two cities in a process of developing a sister-city relationship each bring along members of an ethnic enclave in their cities. It is similar to a double sister-city arrangement between two cities and between two enclaves in these cities. It is their affiliation with City Hall that gave rise to this relationship. The sister-enclave relationship might have existed informally but it is institutionalized through this association model.

The third form, sister enclave by pledge, results from a public arrangement made by an enclave for the purpose of helping another enclave in need of assistance. Any enclave may be encouraged to do so or be assisted in this venture by an umbrella diaspora organization, diaspora leaders, or a church group. This typically involves a diaspora enclave in North America linking with a diaspora enclave in Eastern Europe, the Mediterranean region, or the Middle East in order to provide financial assistance and cooperation, as has happened among the Armenian-American diaspora. The adoption metaphor is sometimes used to explain the nature of these sister-enclave relations; in this context, it refers to the adoption of one group by the other.

These three models of sister-enclave relationships show another facet of the network operation of diaspora sites. Although nestled inside larger urban formations, the sister enclaves manage to maintain extraterritorial linkages and their integration is impacted in one way or another by these crossborder relations. One also sees in a new light the role of the cosmonation in influencing the shape of these local encounters.

We learn from these connections that integration is not simply a hostland or local matter encompassing only the local neighborhood and the rest of the city, but rather a cosmonational process as external agents have become part of the stew of the politics of the local community. In other words, the enclave is not exclusively or uniquely a local residential community, but foremost a neighborhood of globalization deployed as a cosmonational neighborhood.

\section{Borders of the Enclave}

While the sociological literature sheds light on numerous aspects of ethnic neighborhoods, the study of their borders has remained a terra incognita. Enclave borders are not only where the diaspora and the mainstream meet, but also the space at which, when crossed, a homelander becomes a diasporan and vice versa. It is the space that legally separates the homeland from the diaspora. After all, it is the crossing of such space that produces a new identity. Physical borders are easier to identify and analyze because one can observe the layout and actors and distinguish between the core and the periphery. By contrast, spatial borders are less visible and therefore more difficult to apprehend. Yet a focus on diaspora neighborhoods allows us an opportunity to study both sides of the phenomenon. The edges of the diaspora enclave are the edges of the hostland as well as the cosmonation, but these are not identical; they vary because cities are in different states of immigrant policy development and because of different jurisdictional boundaries (Alexander, 2003). This is one visible arena where the cosmonation interacts with the hostland through one of its tentacles. Such an 
interaction is nurtured and supported by the network of sites of the cosmonation as some of their own members may have relocated to this neighborhood. A sharp distinction must be then made between "national boundaries," "diaspora boundaries," and "territorial borders" of the state (Lenoir-Achdjian, 2004). While territorial borders indicate the physical geographical parameters of the state and diaspora boundaries reflect the enclosure of an immigrant group in a delimited place, the national boundaries are more elastic because they are inclusive of the diaspora sites as well. In other words, national boundaries are transformed into "cosmonational boundaries" when they reflect the inclusion and expansion brought about by the deployment of the diaspora.

\section{Homeland Posture}

The diaspora is not alone in forging and maintaining extraterritorial relations with other sites of the cosmonation. The homeland also plays an active role through public policy enacted by the government and individual or group initiatives that civil society endorses. In other words, cosmonational diasporic integration is not simply governed by the efforts and activities of immigrants to reconnect with the rest of the cosmonation while strengthening their ties with the country of residence, but it is also influenced and shaped by initiatives from the homeland, other diaspora sites, and the hostland. An exclusive focus on the hostland as the unique theater of operations is simply not enough if one is to understand the complex nature of the integration process. The homeland intervenes in the process through government policy, establishment of subsidiary shops for commercial activities, products that entrepreneurs make available to the local clientele, clergy they loan to care for diasporic compatriots, and politicians who sporadically visit enclaves for fundraising during electoral campaigns. These undertakings fuel different aspects of immigrant integration. Homeland government intervention in aiding immigrant integration is seen in the case of the implementation of the Plazas Comunitarias in the United States, concocted by the Mexican government (Wides-Munoz, 2008). The goal of such a program is to upgrade the level of education among adult Mexican immigrants in the United States (Delano, 2010: 237). What is striking about this program is not only the formal intervention of the homeland state in diaspora integration in the United States, but also the level of cooperation of hostland institutions in ensuring its success. Delano (2010: 237) mentions among hostland collaborators, "state and local government offices, schools, community organizations, and nonprofit groups." What transpires through this collaborative effort aimed at the integration of the Mexican diaspora is that both homeland and hostland may jointly participate in the same initiative leading to integration in the hostland, homeland, and diasporic network at the same time. It is a simultaneous process whereby each plays a different role in its deployment.

\section{Cosmonational Neighborhood Integration}

There are diverse mechanisms at play that account for the formation, deployment, and maturity of the cosmonational neighborhood. Members of the same cultural group living in either the ancestral homeland or any of its diasporic sites may not necessarily converge at the same time in the same extraterritorial place 
to constitute membership in the local community. The scale of representation may vary as it may first contain more people from the homeland than from other sites; but with time individuals from established diaspora neighborhoods and those in transit may come to inhabit the place through secondary migration in search of jobs, to pursue retirement, or simply to reunite with the rest of the family. In other words, there is something to be said about the formation period as an instance of cosmonational neighborhood development.

The neighborhood operationally becomes cosmonational not simply through shared descent and ancestry of inhabitants, but because individuals, institutions, and associations forcefully engage in transnational practices that link their communities to extraterritorial sites occupied by members of their groups. This is accomplished at the agency level through global interactions with friends, family, and business practices.

At the institutional, organizational, and associational levels, ties between sites develop and operational sites routinely entertain transnational communications to discuss strategies, develop projects, channel funds, and assess outcomes. These happen when headquarters and subsidiaries are managed by members of the same diaspora group. A cosmonational structure may emerge when the leadership of such an institution resides in different sites. In this case, they comanage the institution and therefore cosmonationality is built into the very structure of the institution. An institution may be cosmonational, however, without every member necessarily being cosmonational.

Infrastructure plays a crucial role in facilitating cosmonational interaction and therefore cannot be left untheorized (Simone, 2004). Some infrastructures are developed by the group for that purpose, such as the ethnic newspaper or ethnic television. The paper, although produced in one place, is read by members of the group wherever they happen to reside since it publishes items that are of interest to the larger group. This is how one learns about one's community and other enclaves in the network. The same applies to ethnic television, whose audience is spread beyond the boundaries of any territory. Some other infrastructures are used by the group to channel their transnational activities, such as roads, planes, telephone, and cars that are integrated in these circuits as infrastructures of support. They were not designed for this purpose, but they are bent for use in global interactions.

Hostlands also play a role in allowing the free flow of information between transnational communities. During the Cold War period, cosmonational neighborhoods functioned as frozen quarters because routine exterritorial activities could raise the ire of authorities and place individual freedom at risk; these activities were most often undertaken under the radar of the state and for that reason were self-sanitized. After the collapse of the Soviet Union, hostlands have been more open to a less reactive and more a proactive role in generating and sustaining these cosmonational practices.

Cosmonational integration refers not only to transnational interactions of people and institutions, but also to the transformation of locality, such as the built environment and local operations, to reflect this new reality. This is best expressed in transnational design practices and architectural outcomes (Caims, 2003). 
Cosmonational integration more often than not reflects the visual deployment of this transformation. To the extent that it is possible and it does not interfere with zoning laws, the look and functionality of the diasporic house may resemble homeland designs. Even when such a design is not possible, the façade alone may be done to resemble cultural practices in the homeland, or the traditional cultural use of the house may express this feeling. Sometimes this cosmonational conversion is more subtle and invisible, as some Asian immigrants accomplish by the orientation of the house to meet homeland beliefs and practices. One may speak of the local aspect of cosmonationality, the place where the local and the global is coembedded to become one single entity or process.

Where possible, the distinct form of diaspora architecture is a cornerstone of the integration process, one that highlights the cultural specificity of the neighborhood and distinguishes it from other quarters. For example, the diasporic architecture is a tangible sign that sets Chinatown apart from the housing stock of the rest of the city, and this lures tourists to the neighborhood. The architecture expresses its exoticness as cosmonationality itself is reflected in the built environment. For example, a portion of the house may be a copy of homeland architectural style and the rest may be constructed to meet the requirements of American functionality. Or the architecture may be American in design, but the interior decoration may reflect homeland or other diasporic sites' traditions, especially if over time the neighborhood has been welcoming compatriots from other sites. Also, two or more complementary forms of architectural practice can coexist, as a portion of the home may be dedicated to a shrine where devotional practices and rituals take place. These are choreographies of homeland performances inside a hostland compound. These two architectural forms are found to be well integrated in the production and sustenance of the cosmonational neighborhood.

Diaspora architecture teaches us that it is part and parcel of the integration of the neighborhood in the cosmonation by becoming itself cosmonational, that is, facilitating, mirroring, and reflecting a panoply of the group's house-making, house-decorating, and house-living traditions. This shows how architectural style migrates from one site to another in the same way that goods, information, and people do. It also suggests that cosmonationality is not confined to any specific area, but permeates the everyday life of the neighborhood. The focus on architecture opens a new window, shedding light on the contribution of different blocs in the overall constitution of the cosmonation.

\section{Cosmonational Policy of Municipal Government}

Calling an immigrant neighborhood an ethnic quarter or diaspora enclave does not mean the same thing: these two concepts are not interchangeable. Each is loaded with a set of assumptions that influence municipal policy vis-à-vis the group; each positions the group differently in society; and each refers to a different semantic field and conceptual domain. This naming is a form of branding that is inherently not neutral because it carries with it meanings that lodge an entity in a specific structural position. 
The term ethnic conveys that the group is of a different stock than the mainstream; it is a local group that is most often marginalized; municipal policy must gear toward its integration in society; and the success of its integration can be gauged by the level and speed with which complete assimilation is achieved. Two relationships can be singled out to understand the ethnic enclave in this vision: horizontal ties with the rest of the nation (mainstream community and other ethnic groups) and vertical linkages with the state (municipal and national government).

In contrast, diaspora enclave implies that the global inhabits the local; foreignness or foreign attachment is a characteristic of the group; the homeland (culture, language, and religion) is part of the definition of the group; and their cultural ways cannot be understood without reference to the homeland.

While the ethnic metaphor implies locality, sedentariness, and enclosure in a municipality, the diaspora concept refers to interconnection with other sites, crossborder networking, and global expansion. Municipal policy of ethnic enclosure does not fit the diaspora enclave's propensity for cosmonational integration. The enclave becomes a site of double loyalty, tending to the affairs of the cosmonation as well as those of the hostland. This frontier site transacts with both sides for a smooth integration into both.

Municipal policy toward diaspora integration needs some adjustment in view of the expanding parameters of the problem. It perhaps needs reorientation to account for the cosmonationalization of integration, a transformation of municipal diaspora policy from an ethnic to a diasporic conceptualization to better understand the new order of things. And it means allowing municipal diasporic policy to be either congruent, disruptive, or corrective in order to positively influence and manage the direction of diasporic neighborhood evolution.

Casting the enclave as a node of a cosmonation provides a more productive and insightful dimension for interaction, transaction, or intervention by the municipal government. It is so because this perspective relocates the enclave inside a transnational network instead of seeing it simply as a locale inside the bounded territory of a municipality.

The shift of municipal policy from an exclusively local concern to a strategy that takes into consideration the existence of the cosmonational operation of the enclave can be seen in a number of areas. These policy shifts are recently robust in their implementation. A new consciousness is taking place whereby the municipal government no longer sees itself as capable of resolving problems of ethnic enclaves by focusing exclusively on the local. Signs of this shift were already apparent with the rise of the sister-cities movement in multiethnic cities in North America following the Second World War, especially in places where diasporans played a leading role in these outcomes.

Municipalities routinely use diaspora groups, individuals, and institutions to reach out to their homelands as part of the municipal arsenal of best practices. Governing the enclave through recourse to the homeland when needed is part of the new structure of municipal governance. The municipality's use of the diaspora to reach the homeland is sometimes activated during a moment of 
crisis in the homeland or the diaspora enclave. At other times, it is undertaken as part of the city's foreign relations with a diaspora's homeland.

After the earthquake that flattened Port-au-Prince in 2010, the hôtel de ville of Paris thought of helping the victims of this natural disaster and did so when appropriate by channeling financial aid through Haitian-French associations. Not only did City Hall show that it cared, but it also enlisted and empowered the Haitian-French diaspora community residing in the Paris metropolitan area to be part of the process. This was not only a way to maintain good relations between the diaspora community and City Hall, but also between the Haitian diaspora community and the homeland; and to the extent that the community collaborated with other diaspora sites, City Hall also contributed to the maintenance of good relations among various sites and actors of the cosmonation. This municipal government intervention displays an example of the shift in policy from the local to the global, indirectly highlighting the centrality of the cosmonation in the spheres of action of the diaspora enclave.

Sister-city arrangements also showcase the role of the diaspora in linking city policy to the homeland via the diaspora enclave. These arrangements are made by city officials with the calculation of earning diaspora votes on election day. These may not obviously be relations that the city in the hostland should undertake, but the lure of the diaspora vote constitutes a factor in maintaining good relations between City Hall and the enclave. These policies are directed toward pleasing the diaspora as well as reinforcing harmony between the local government and the local diasporic community. In this case, maintaining good relations with the diaspora is the sought-after dividend and explains the city's relations with the diaspora's homeland.

In a different scenario illustrating how city relations with a foreign government have led to a measure of improvement in the relations of the city with a diaspora enclave in its midst, the city government sometimes reaches out to the homeland to find teachers of the diaspora native language so that they may be hired to meet the educational needs of diaspora children. This formula of using the homeland to strengthen relations between the local government and the diaspora enclave was at its peak of popularity during the Reagan administration when bilingual education was adopted as a policy by local municipal governments in the United States to enhance the education of second-generation immigrant children.

\section{Municipal Policy Models}

Municipal policy concerning the integration of ethnic neighborhoods has evolved over time, but more speedily since the end of World War II. It has taken different orientations based on the prevalent ways in which relations of city government with the ethnic neighborhood have been conceptualized and implemented. The following municipal policy models are identified from a history of policy practices.

The "minoritized enclave model" ("internal colonialism") projects the ethnic quarter as a locus for application and imposition of the dominant sector's urban rules and zoning practices on a subjugated segment of the city (Diaz, 2005). It 
unveils a top-down hierarchical relationship as the natural order of things. The state or municipal government decides on the role it expects the ethnic quarter to play in harmonization of all the active poles of the municipality: a policy of assimilation that is proposed as the best solution to the ethnic integration problem. The framework of such a policy, however, is developed with little or no insight from the ethnic neighborhood in terms of what they want for their area. It is the worst expression of top-down urban planning.

The "ethnic integration model" seeks to cohere ethnic neighborhoods into dynamic groups so that they may favorably negotiate with City Hall on behalf of their communities (Favell, 2001). It consists of co-opting ethnic leaders into collaborating on plans for the city that directly affect ethnic communities, such as those geared toward urban renovation. Their collaboration is sought during both the planning and implementation phases.

The "multiculturalist model" consists of the consolidation of ethnic quarters as constitutive of the urban mosaic (Vasta, 2007). This is a project geared toward harmonization and recognition of their contributions to the city. Particular attention is paid to the role of ethnic associations and federations because of the aid they furnish to their clientele and, more specifically, the services they offer to immigrants in need. Multiculturalism comes into being as a state municipal project rather than an ethnic one. Thus, when the state decides that the model is no longer useful for whatever reason, it is disbanded, as is the case in the Netherlands. The borders of multiculturalism are shaped and policed by the municipality.

The "municipal internationalism model" consists of the engagement of one city with a foreign city for mutual cooperation (Bontenbal and van Lindert, 2009). It has a broader scope than integration of ethnic neighborhoods. The ethnic factor comes into play when such an initiative is derived from the ethnic group or when City Hall decides to pair the ethnic neighborhood with another ethnic neighborhood of the same ancestry in the creation of a sister-city arrangement. This model materializes in the use of association services to channel aid to the homeland or act as partners in the process of decentralized cooperation. It is a selective form of internationalism, but not a coherent and full-fledged transnational or global policy. Such an internationalist posture serves first and foremost as a backup policy objective of the state.

In the "civic integration model" (Joppke, 2007) the accent is placed more on the socioeconomic integration of immigrants than the preservation of their ethnic heritage. Immigrants are encouraged to actively participate in the civic life of the city through voting, association membership, church attendance, and communal activities in an effort to enhance adaptation and prevent isolation and ghettoization. This model is not new and aims at achieving integration through the strengthening of the communal ties of the city. It was most recently advocated as a policy recommendation by the Council of Europe ( $/$ bid).

While no city has yet developed a cosmonational policy-because their international engagement is more to support their country's foreign policy than to consolidate a cosmonation-there are cosmonational features that can be detected in their practices. This view perhaps indicates that a city's international 
engagement can be interpreted differently by the municipal government and the diaspora in its midst. The city sees its foreign relations in terms of expanding its networks of friends, while the diaspora sees these engagements as a reinforcement of their cosmonational projects.

\section{Conclusion}

In this analysis of diasporic neighborhood integration, we see its multiple attachments to the hostland, homeland, and all of the diasporic sites in which compatriots reside around the globe. The process of integration cannot be understood without paying attention to these extraterritorial factors, they are part and parcel of daily life in the local neighborhood. The local neighborhood contributes with its initiatives to the enhancement of the city's foreign engagement with the homeland; the homeland economic wellbeing (by the remittances sent to family and friends left behind); and other diasporic settlements (by serving as a potential destination site for those engaged in secondary migration). The neighborhood is entangled in a global circuit of interactions, mobility, and practices-both online and offline-and this is the logic of the operation that we have attempted to circumscribe, deconstruct, analyze, and unveil, while seeing the diasporic neighborhood as both a local community and a distinct site of the cosmonation.

\section{References}

Abrahamson Mark (1996) Urban Enclaves: Identity and Place in America, New York, St. Martin's Press, $152 \mathrm{p}$.

Alba Richard and Nee Victor (2003) Remaking the American Mainstream: Assimilation and Contemporary Immigration, Cambridge, Harvard University Press, $367 \mathrm{p}$.

Alexander Michael (2003) Local Policies Toward Migrants as an Expression of Host-Stranger Relations: A Proposed Typology, Journal of Ethnic and Migration Studies, 29 (3), pp. 411-430.

Aytar Volkan and Rath Jan (2012) Selling Ethnic Neighborhoods: The Rise of Neighborhoods as Places of Leisure and Consumption, New York, Routledge, $176 \mathrm{p}$.

Basch Linda, Glick Schiller Nina and Szanton Blanc Christina (1994) Nations Unbound:Transnational Projects, Postcolonial Predicaments and Deterritorialized Nation-States, Amsterdam, Gordon and Breach, 344 p.

Ben-Rafael Eliezer and Sternberg Yitzhak (2009) Transnationalism: Diasporas and the Advent of a New (dis)Order, Boston, Brill, $784 \mathrm{p}$.

Bjornstrom Eileen (2011) To Live and Die in LA County: Neighborhood Economic and Social Context and Pre-Mature Age Specific Mortality Rates Among Latinos, Health and Place, 17 (1), pp. 230-237.

Bontenbal Marike and van Lindert Paul (2009) Transnational City-to-City Cooperation: Issues Arising From Theory and Practice, Habitat International, 33 (2), pp. 131-133. 
Bouma-Doff van der LaanWenda (2007) Confined Contact: Residential Segregation and Ethnic Bridges in the Netherlands, Urban Studies, 44 (5-6), pp. 997-1017.

Brown Susan K. (2007) Delayed Spatial Assimilation: Multigenerational Incorporation of the Mexican Origin Population in Los Angeles, City and Community, 6 (3), pp. 193-209.

Brubaker Rogers (2005) The 'Diaspora' Diaspora, Ethnic and Racial Studies, 28 (1), pp. 1-19.

Caims Stephen (2003) Drifting: Architecture/Migrancy, New York, Routledge, $313 \mathrm{p}$.

Catney Gemma, Finney Nissa and Twigg Liz (2011) Diversity and the Complexities of Ethnic Integration in the UK, Journal of Intercultural Studies, 32 (2), pp. 107-114.

Cheung Gordon C. K. (2004) Chinese Diaspora as a Virtual Nation: Interactive Roles Between Economic and Social Capital, Political Studies, 52 (4), pp. 664-684.

Delano Alexandra (2010) Immigration Integration vs. TransnationalTies? The Role of the Sending State, Social Research, 77 (1), pp. 237-268.

Diaz David R. (2005) Barrio Urbanism: Chicanos, Planning, and American Cities, New York, Routledge, 360 p.

Dustmann Christian, Fabbri Francesca and Preston lan (2011) Racial Harassment, Ethnic Concentration and Economic Conditions, Scandinavian Journal of Economics, 113 (3), pp. 689-711.

Ellis Mark and Almgren Gunnar (2009) Local Contexts of Immigrant and SecondGeneration Integration in the United States, Journal of Ethnic and Migration Studies, 35 (7), pp. 1059-1076.

Evans Mariah D. R .(2005) Do Ethnic Enclaves Benefit or Harm Linguistically Isolated Employees? Research in Social Stratification and Mobility, 22, pp. 281-316.

Favell Adrian (2001) Integration Policy and Integration Research in Europe: A Review and Critique, in T. Alexander Aleinikoff and Douglas Klusmeyer Eds., Citizenship Today: Global Perspectives and Practices, Washington, Brookings Institution Press, 424 p.

Fong Eric and Shibuya Kumiko (2005) Multiethnic Cities in North America, Annual Review of Sociology, 31, pp. 285-304.

Glick Schiller Nina et. al. (1992) Towards a Transnational Perspective on Migration, New York, New York Academy of Sciences, 259 p.

Godfrey Brian J. (1988) Neighborhoods in Transition: The Making of San Francisco's Ethnic and Noncomformist Communities, Berkeley, University of California Press, 233 p.

Maarten van Ham and David Manley (2009) The Effect of Neighbourhood Housing Tenure Mx on Labour Market Outcomes: A Longitudinal Investigation of Neighbourhood Effects, Journal of Economic Geography, Volume 10, Issue 2, pp. $257-282$.

Hum Tarry and Krase Jerome (2004) Immigrant Global Neighborhoods in New York City, Research in Urban Sociology, 7, pp. 25-55. 
Johnston Ron, Forrest James and Poulsen Michael (2002) The Ethnic Geography of EthniCities: The 'American Model' and Residential Concentration in London, Ethnicities 2 (2), pp. 209-235.

Joppke Christian (2007) Beyond National Models: Civic Integration Policies for Immigrants in Western Europe, West European Politics, 30 (1), pp. 1-22.

Kanas Agnieszka et al. (2011) Social Contacts and the Economic Performance of Immigrants: A Panel Study of Immigrants in Germany, Bonn, Forschungsinstitut zur Zufunft der Arbeit/Institute for the Study of Labor, $44 \mathrm{p}$.

Karim Karim H. (2006) Nation and Diaspora: Rethinking Multiculturalism in a Transnational Context, International Journal of Media and Cultural Politics, 2 (3), pp. 267-282.

Kivisto Peter (2001) Theorizing Transnational Immigration: A Critical Review of Current Efforts, Ethnic and Racial Studies, 24 (4), pp. 549-577.

Krase Jerome and Hum Tarry (2007) Immigrant Global Neighborhoods: Perspectives from Italy and the United States, Research in Urban Sociology, 8, pp. 97-119.

Kymlicka Will and Banting Keith (2010) Canadian Multiculturalism: Global Anxieties and Local Debates, British Journal of Canadian Studies, 23 (1), pp. 43-72.

Labelle Micheline and Midy Franklin (1999) Re-reading Citizenship and the Transnational Practices of Immigrants, Journal of Ethnic and Migration Studies, $25(2)$, pp. 213-232.

Labelle Micheline and Rocher François (2009) Immigration, Integration, and Citizenship Policies in Canada and Quebec: Tug of War Between Competing Social Projects, in Ricard Zapata-Barrero Ed., Immigration and Self-Government: Normative Questions and Institutional Projects, Bruxelles, P.I.E. Peter Lang, pp. 57-86.

Laguerre Michel S. (1998) Diasporic Citizenship, New York, Macmillan, 222 p.

Laguerre Michel S. (1999) Minoritized Space: An Inquiry into the Spatial Order of Things, Berkeley, Berkeley Public Policy Press, 152 p.

Laguerre Michel S. (2000) The Global Ethnopolis: Chinatown, Japantown, and Manila-town in American Society, New York, MacMillan Press, 216 p.

Laguerre Michel S. (2003) Urban Multiculturalism and Globalization in New York City, Basingstoke, Palgrave Macmillan, 207 p.

Laguerre Michel S. (2006) Diaspora, Politics, and Globalization, New York, Palgrave Macmillan, $220 \mathrm{p}$.

Laguerre Michel S. (2007) Diasporic Globalization: Reframing the Local/Global Question, Research in Urban Sociology, 8, pp. 15-40.

Laguerre Michel S. (2008) Global Neighborhoods: Jewish Quarters in Paris, London and Berlin, Albany, State University of New York Press, 276 p.

Laguerre Michel S. (2010) A Cosmonational Theory of Global Neighborhoods, Amerasia Journal, 36 (3), pp. 15-33.

Laguerre Michel S. (2013) Parliament and Diaspora in Europe, New York, Palgrave Macmillan Press, 212 p. 
Lainer-Vos Dan (2010) Diaspora-Homeland Relations as a Framework to Examine Nation-Building Processes, Sociology Compass, 4 (10), pp. 894-908.

Lenoir-Achdjian Annick (2004) Ambivalence in Self-Representation Among Armenians in the Diaspora or the Difficulty of Not Being Either Here orThere, but Between the Two, Canadian Ethnic Studies, 36 (2), pp. 76-100.

Levitt Peggy (2001) The Transnational Villagers, Berkeley, University of California Press, $281 \mathrm{p}$.

Levitt Peggy and Khagram Sanjeev Eds. (2008) The Transnational Studies Reader: Intersections and Innovations, New York, Routledge, 575 p.

Light Ivan and Gold Steven J. (2000) Ethnic Economies, San Diego, Academic Press, $302 \mathrm{p}$.

Lin Ken-Hou (2011) Do Less-Skilled Immigrants Work More? Examining the Work Time of Mexican Immigrant Men in the United States, Social Science Research, 40 (5), pp. 1402-1418.

Liu Cathy Yang (2012) Intrametropolitan Opportunity Structure and the SelfEmployment of Asian and Latino Immigrants, Economic Development Quarterly, 26 (2), pp. 178-192.

Logan John R. and Zhang Charles (2010) Global Neighborhoods: New Pathway to Diversity and Separation, American Journal of Sociology, 115 (4), pp.1069-1109.

Magee William, Fong Eric and Wilkes Rima (2008) Neighborhood Ethnic Concentration and Discrimination, Journal of Social Policy, 37 (1), pp. 37-61.

McKee James B. (1993) Sociology and the Race Problem: The Failure of a Perspective, Champaign, University of Illinois Press, 384 p.

Montgomery Alesia F (2011) Ghettos and Enclaves in the Cross-Place Realm: Mapping Socially Bounded Spaces Across Cities, International Journal of Urban and Regional Research, 35 (3), pp. 659-675.

Morawska Ewa (2003) ImmigrantTransnationalism and Assimilation: A Variety of Combinations and the Analytic Strategy it Suggest, in Christian Joppke and Ewa Morawska Eds., Toward Assimilation and Citizenship in Liberal Nation-States, Basingstoke, Palgrave Macmillan, pp. 133-176.

Murdie Robert and Ghosh Sutama (2010) Does Spatial Concentration Always Mean a Lack of Integration? Exploring Ethnic Concentration and Integration in Toronto, Journal of Ethnic and Migration Studies, 36 (2), pp. 293-311.

Özüekren, A. Sule (2003) Ethnic Concentration at the Neighborhood Block Level: Turks in a Greater Stockholm Suburb (1989 and 1999), Housing, Theory and Society, 20 (4), pp. 172-182.

Patterson Rubin (2006) Transnationalism: Diaspora-Homeland Development, Social Forces, 84 (4), pp. 1891-1907.

Pedraza Silvia (1999) Assimilation or Diasporic Citizenship? Contemporary Sociology, 28 (4), pp. 377-381.

Portes Alejandro and Jensen Leif (1989)The Enclave and the Entrants: Patterns of Ethnic Enterprise in Miami before and after Mariel, American Sociology Review, 54 (6), pp. 929-949. 
Radhakrishnan Smitha (2008) Examining the "Global" Indian Middle Class: Gender and Culture in the Silicon Valley/Bengalore Circuit, Journal of Intercultural Studies, 29 (1), pp. 7-20.

Roseman Curtis C., Dieter Laux Hans and Thieme Gunter (1996) EthniCity : Geographic Perspectives on Ethnic Change in Modern Cities, Lanham, Rowman and Littlefield Publishers, 309 p.

Sassen Saskia (2001) The Global City, Princeton, Princeton University Press, $472 \mathrm{p}$.

Shain Yossi (1999) Marketing the American Creed Abroad: Diasporas in the US and their Homelands, Cambridge, Cambridge University Press, 294 p.

Sheffer Gabriel (2003) Diaspora Politics: At Home Abroad, New York, Cambridge University Press, 308 p.

Simone AbdouMaliq (2004) People as Infrastructure: Intersecting Fragments in Johannesburg, Public Culture, 16 (3), pp. 407-429.

Vasta Ellie (2007) From Ethnic Minorities to Ethnic Majority Policy: Multiculturalism and the Shift to Assimilationism in the Netherlands, Ethnic and Racial Studies, 30 (5), pp. 713-740.

Vervoort Miranda (2012) Ethnic Concentration in the Neighborhood and Ethnic Minorities' Social Integration: Weak and Strong Social Ties Examined, Urban Studies, 49 (4), pp. 897-915.

Vervoort Miranda, Dagevos Jaco and Flap Henk (2012) Ethnic Concentration in the Neighborhood and Majority and Minority Language: A Study of First and Second-Generation Immigrants, Social Science Research, 41 (3), pp. 555-569.

Viltard Yves (2008) Conceptualiser la "diplomatie des villes". Ou I'obligation faite aux relations internationales de penser l'action extérieure des gouvernements, Revue française de science politique, 58 (3), pp. 511-533.

Wides-Munoz Laura (2008) In Twist to Immigration Debate, Mexico Quietly Helps Teach Citizens Who Have Emigrated to United States, Associated Press, September 24, p. 1. 


\section{Michel S. Laguerre}

\section{Cosmonational Integration of Diaspora Enclaves}

This essay re-conceptualizes diasporic integration as an object of study in order to unveil the true nature and parameters of the problem. In contrast to previous studies of immigrant communities, which use the assimilation, multiculturalism, or transnationalism approach in the deconstruction of ethnic formations, this new model of integration-the cosmonational model-relocates the ethnic enclave inside a global circuit of interactions, views it as enmeshed in the logic of an ensemble of interlinked sites, and consequently posits integration into a hostland as a cosmonational process.

\section{$\cdots$ L'integration cosmonationale des enclaves diasporaines}

Cet essai prend pour objet d'étude la question de l'intégration diasporaine. À l'encontre d'autres études des communautés ethniques qui utilisent l'approche assimilationiste, multiculturaliste ou transnationaliste dans la déconstruction des formations ethniques, le nouveau modèle d'intégration proposé ici - le modèle cosmonational - relocalise le quartier ethnique à l'intérieur d'un circuit mondial d'interactions. Il le présente comme enchevêtré dans la logique d'un réseau de sites imbriqués les uns dans les autres, et en conclusion montre que l'intégration diasporaine dans le pays de résidence est un processus cosmonational.

\section{...: Integración cosmo-nacional de los enclaves de la diáspora}

Este ensayo re-conceptualiza la integración de la diáspora como objeto de estudio para poder revelar la verdadera naturaleza y parámetros del problema. A diferencia de estudios anteriores sobre las comunidades de inmigrantes que usan el enfoque de la asimilación, del multiculturalismo, o de lo transnacional en la deconstrucción de las configuraciones étnicas, este nuevo modelo de integración-el modelo cosmo-nacional-reubica el enclave étnico dentro de un circuito global de interacciones y lo presenta como imbricado en la lógica de un conjunto de sitios interconectados entre si. El autor concluye que la integración de la diáspora en el país de residencia constituye un proceso cosmo-nacional. 